\title{
The Effect of External Debt on Inflation Rate in Kenya, 1972-2012
}

\author{
Fredrick Tsofa Mweni ${ }^{1}$, Amos Njuguna $^{1} \&$ Timothy Oketch ${ }^{1}$ \\ ${ }^{1}$ Chandaria School of Business, Nairobi, Kenya \\ Correspondence: Fredrick Tsofa Mweni, Chandaria School of Business, P.O Box 14634-0800 Nairobi, Kenya. Tel: \\ 254-72-268-3151.
}

Received: July 10, 2016

Accepted: July 16, 2016

Online Published: July 18, 2016

doi:10.5430/ijfr.v7n4p198

URL: http://dx.doi.org/10.5430/ijfr.v7n4p198

\begin{abstract}
The purpose of the paper was to review existing studies on external debt and inflation and establish the effect of external debt on inflation in Kenya over the period of 1972-2012. The study used real annual time series data obtained from IMF International Financial Statistics database. The time series data was tested for stationarity using Augmented Dickey-Fuller (ADF), tests for heteroskedasticity, autoregressive conditional heteroskedasticity $(\mathrm{ARCH})$, autocorrelation and normality were done to ensure the data does not violate the assumptions of classical linear regression model (CLRM). A macroeconomic debt growth model using ordinary least square regression was used to estimate the relationship between external debt and inflation. Descriptive statistics indicates that Kenya experienced high levels of inflation, with mild fluctuations. The highest levels of inflation were recorded in 1991 and 2008, due to the OPEC oil crisis and post-election violence, respectively. In terms of correlation, the study reveals that external debt and inflation showed that external debt and inflation are negatively correlated, with a Spearman's correlation coefficient of -0.1768 with a $\mathrm{P}$ value of 0.2687 . Regression results showed that external debt has a positive and significant effect on inflation, with an F statistic of 7.14 with a $P$ value of 0.011 . The study concludes that there is a significant effect of external debt on inflation. The study recommends sustaining lower inflation rates through tight fiscal and monetary policies, financing of budget deficit from non-inflationary sources, implementation of price stabilization program by subsiding basic food items, and effectively managing external debt.
\end{abstract}

Keywords: external debt, debt accumulation, inflation rate, gross domestic product, public expenditure

\section{Introduction}

Achieving sustainable economic growth and development is a major concern for all countries (Sabbir, 2009). Many world economies are characterized by low capital formation and a shortage of resources to meet increasing public expenditures (Aliko \& Arowolo, 2010). With continuous increases in public expenditure and widening budgetary deficits, majority are forced to pursue domestic and foreign borrowing to plug budgetary deficits and fund development (Saheed, Sani, \& Idakwoji, 2014). Internally, governments can raise funds through taxation, coinage, or internal debt, with coinage least preferred because of the fear of fuelling inflation (Sabbir, 2009). In a review of 26 empirical studies from 1983 to 2012, McBride (2012) noted that studies have consistently showed a negative relationship between taxes and economic growth. It was contended that there is a limit to which the government can raise taxes to finance public expenditures (McBride, 2012). Treasury bills and government bonds is the most common way of raising domestic debt. Higher domestic borrowing may increase interest rates and crowd-out the private sector hence slowing growth (Miller \& Foster, 2012; Checherita \& Rother, 2010) thus necessitating external debt.

External debt comprises the external monetary debt obligations, including guarantee commitments by government to non-residents in other currencies, usually in US dollar. Adjusted for external obligation, external currency debt comprises; public and publicly guaranteed debt, medium and long term (longer than one year) debt such as bilateral and multilateral debt as well as commercial loans and credits. It also comprises short term debt (less than one year) from institutional lenders, private non-guaranteed debt, IMF debt, and debt obligation to residence in foreign exchange currency (Khattak, 2008).In the face of public deficits, the choice of financing source is informed by the cost and risk, and various objectives such as low inflation, stable exchange rate, low interest rate, favourable yield curves, adequate foreign reserve cover, and activity in the domestic market (Beaugrand, Loko, \& Mlachila, 2002). 
According to Nelasco (2012), external borrowing has become indispensable in the modern world because it supplements domestic savings and allows countries to carry out productive activities (Ezeabasili, 2011). Gana, (2002) reiterates that external borrowing is desirable and can provide the financing necessary for accelerated economic growth, provided they are channelled to increase the productive capacity of the economy and promote economic growth and development. Nelasco (2012) adds that the process of capital formation and industrialisation require heavy investments in infrastructure like roads, railway lines, irrigation channels and power houses which force the government to seek external borrowing. Speedy industrialisation necessitates heavy import of capital goods such as machinery and equipments and technical know- how from abroad. The governments have to borrow heavily from foreign countries to make up the deficit in the balance of payments, caused by heavy imports (Nelasco, 2012).

On the contrary, when the external debt is not sustainable, it poses a risk on the economic growth and prosperity of a country (Gebru, 2015). However, heavy external debt does not necessarily imply slow economic growth; rather, it is the inability of the country to meet its debt obligations. As such, countries must utilize debt productively, and create employment to expand their revenue base, and service their debt appropriately. Traditionally, the effect of external debt is examined by assessing external indicators such as debt-to-GDP ratios, and macroeconomic indicators such as GDP, inflation, interest rates, foreign reserves, balance of trade, and level of investment (Shabbir, 2009). The study was restricted to assessing the effect of external debt on inflation.

According to Asmamaw (2011), inflation is a global concern that continually threatens all economies, whether developed or developing, due to its undesirable effects. Keynesian theories demonstrate that inflation occurs when demands exceeds the potential of the economy (Gebru, 2015). There are various arguments on the effect of external debt on inflation. According to Choong et al (2010), since a government borrows to plug its budget deficits, external borrowing is eventually monetized and therefore influences inflation. A country with a large debt level is more likely to experience high interest rates leading to the implementation of monetary policies that reduce these rates. The result of such an expansionary policy may reduce interest rates over the short term but lead to higher interest rates and inflation higher or unchanged over the long term (Choong et al., 2010).

According to Ogunmuyiwa (2011) government debt-to-GDP ratios can depress economic growth and have immediate effects on inflation and national solvency. On the contrary, while the relationship between public debt and growth is clear and significantly similar in both developed and emerging economies, the relationship between public debt and inflation remains unclear. Reinhart \& Rogoff (2010) reported no systematic relationships between inflation and high debt levels and inflation in advanced economies. However, higher debt levels in emerging economies correlated with high inflation (Reinhart \& Rogoff, 2010). The 'safe' debt-to-GDP thresholds depend on a country's default and inflation history, and can be as low as 15\% (Reinhart, Rogoff, \& Savastano, 2003; Patillo, Poirson, \& Ricci, 2011). The resultant effect of high debt levels create high debt burden and makes debt servicing a threat to economic stability, particularly in developing countries (Suleiman \& Azeez, 2012).

According to the World Bank International Debt Statistics (2013), the combined stock of developing countries' external debt rose from $\$ 4.4$ trillion in 2010 to $\$ 4.9$ trillion at the end of 2011, reflecting net debt inflows of $\$ 464$ billion. Short-term debt was the fastest growing component, rising by $18 \%$ in 2011 as compared to a 9\% increase in the stock of outstanding long term external debt. Most short-term debt was trade related and, measured against developing countries' imports, decreased slightly, to $17 \%$ compared to $18 \%$ in 2010 . The stock of long term debt at end 2011 was fairly evenly divided between publicly guaranteed debt, $51 \%$ and debt owed to private nonguaranteed borrowers, $49 \%$ although the latter rose twice as fast as the former in $2011,12 \%$ as compared to $6 \%$. This was a complete turnaround from 2010 when long term public and publicly guaranteed debt rose at a rate twice that of private nonguaranteed debt. Developing countries' debt stock remained moderate, an average of $22 \%$ of GNI and $69 \%$ of export earnings and risks associated with the fact that short-term debt constituted $26 \%$ of debt stock at end 2011 were mitigated by international reserves. The global economic crisis forced some developing countries to draw down international reserves but, in aggregate, developing countries recorded an accumulation of international reserves since the onset of the crisis: equivalent to $121 \%$ of external debt stock at end 2011 (World Bank, 2013).

In Kenya, there has been a rapid increase in total external debt in Kenya over the past years. Data from the Kenya Sovereign Bond Prospectus (2014) shows that the total external debt owed to lending countries increased from $\$ 2$, 859 million in 2011 , to $\$ 2,923$ million in 2012 , and $\$ 3,300$ million in 2013 . The rapid increase is attributed to increased lending from China which increased from $\$ 361.10$ million in 2011, to $\$ 466$ million in 2012, and $\$ 940$ million in 2013. The total debt owed to international organizations increased from $\$ 8,044$ million in 2010 , to $\$ 9,194$ million in 2012, and \$10,686 million in 2013 (Kenya Sovereign Bond Prospectus, 2014). 
The rapid increases have led to concerns that the economy risks rapid debt escalation when planned borrowing for the mega projects in the infrastructure development plan under Vision 2030 may erode the country's ability to meet its debt obligations and occasion a debt crisis (KENDREN, 2012). IMF (2013) and World Bank (2013) have recommended that Kenya should exploit alternative and innovative funding mechanisms such as public-private partnerships to avoid a debt crisis. These concerns, coupled with the recent global financial crisis and expansions in government expenditure demands renewed attention of researchers on the relationship between external debt and macroeconomic indicators.

In the 2014/2015 Budget, overall spending increased by $8 \%$ from Kes 1.64 trillion in 2013/14 to Kes 1.77 trillion in 2014/15. The budget deficit will be financed by bilateral and multilateral loans and grants, since it is unlikely that the Kenya Revenue Authority will collect the projected revenue (IAS, 2014). Kenya's budget deficit as a percentage of GDP stood at $14.45 \%$ in 2013 and 9\% in 2014 and remains the highest in the East African region (KPMG, 2013). Overall budget deficit increased from KES 505.2 billion in 2012/13 to KES 614 billion in 2013/2014 (IAS, 2013). The 2014/15 budget deficit reduced to KES 342.6 billion (IAS, 2014), but increased to a high of KES 603.2 billion in 2015/16, and a further KES 691.5 billion in the 2016/17 budget (The National Treasury, 2015, 2016).

With public discontent over the rising cost of living, the government has been very reluctant to increase the tax rates, leaving the borrowing option as the most preferred alternative (Hira, 2011). As a result, Kenya's public debt surged to 1.9 trillion in 2013, comprising of $44.5 \%$ external and 55.5\% domestic debt (Quarterly Economic and Budgetary Review, 2013). Recent data from the Kenya Sovereign Bond Prospectus (2014) shows an increase in total external debt owed to lending countries increased from $\$ 2,859$ million in 2011 , to $\$ 2,923$ million in 2012, and $\$ 3,300$ million in 2013; and an increase in total debt owed to international organizations increased from $\$ 8,044$ million in 2010, to $\$ 9,194$ million in 2012, and \$10,686 million in 2013 (Kenya Sovereign Bond Prospectus, 2014).

Even though Kenya needs external funding to drive its development agenda, the potential effect of rising external debt levels on macroeconomic indicators must be critically examined to ensure that not only are the country's financing needs achieved, but also that debt re payment obligations are met at the lowest possible cost over the medium and long run, consistent with prudent degree of risk (IMF, 2010; IEA, 2014). However, literature on the relationship between external debt and inflation is scanty.

The purpose of the study was to investigate the relationship between external debt and inflation in Kenya. Therefore, main research question can be stated as: what is the relationship between external debt and inflation in Kenya?

\section{Theoretical Review}

Economists have long explored channels through which external debt can hamper economic growth and affect other macroeconomic variables (Sabbir, 2009). One of the main theories is the debt overhang theory. Debt overhang refers to a situation where the debt stock of a nation exceeds its future capacity to repay it. The theory stipulates that when countries have higher external debt to GDP ratio, they may find relatively less funds available to provide an environment conducive for business and promote investment, which further deteriorate the current level of economic growth. This lack of funds coupled with deteriorating economic environment causes a decline in investments on health, infrastructure and health.

According to Presbitero (2006), the stock of debt has an effect on economic performance via the uncertainty associated with its effect on inflation. High debt stocks are associated with high and volatile inflation. Further, high debt stock levels increase risks of default, rescheduling and increase the volatility of future capital inflows. External debt creates an acute debt overhang problem because the country has a much narrower range of tools for reducing debt, since typically neither inflation nor financial repression is possible (Reinhart, Reinhart \& Rogoff, 2012). Excessive debt is linked with economic uncertainty and instability and forces the government to adopt financially repressive policies to control inflation to meet financial need with seigniorage (monetization of deficit), and reduce government spending on interest paid on government debt (Hwang et al., 2010).

\subsection{Empirical Review}

Across the world, raising sufficient funds to finance government projects is a major concern. No country has adequate resources to meet all its budgetary needs. Implementing development policies, particularly in developing countries remain a major challenge (Mailafiya, 2010). Due to inadequate resources, countries turn to external debt to meet its expenditure needs. External debt is sought by both developed and developing countries (Abukabar, 2011). However with accumulation of debt rises higher debt servicing charges and a threat to the stability of economies. Further, high debt servicing may lead to debt overhang (Atique \& Malik, 2012). Baxter and Stockman (2011) define inflation as the overall general upward price movement of goods and services in an economy (often caused by an increase in the 
supply of money or high cost of doing business); usually as measured by the Consumer Price Index and the Producer Price Index. According to Ali (2012) external debt can exert both positive and negative effects on the economy. When utilized for productive investment, it is helpful. However, when used for private and public consumption purposes, it does not help in improving the government's revenue base and exerts a negative effect on the economy.

Suleiman and Azeez (2012) noted that large accumulation of debt exposes the nation to high debt burden and its servicing is a major threat to the growth of the nation. In a study of Nigeria, the researchers demonstrated that Nigeria has experiencing growth in its stock of external debt, the country witnessed economic growth up to 1970s and thereafter seems to be crawling and retrogressing in some aspects. This is evident in the fact that the oil-rich country has been hobbled by political instability, inadequate and inefficient infrastructures, poor educational system, inadequate and inefficient health facilities, corruption, unemployment, inflation and poor macroeconomic management. The study concluded that external debt has exerted a negative effect on economic growth and macroeconomic variables such as inflation. However, there are other studies done in Nigeria that showed a positive effect on economic growth (Ajayi \& Oke, 2012).

Mustafa (2008) conducted a research to test two main hypotheses: the first is that the external debt is less inflationary when financial markets are well developed. The second is that the effects of the determinants of inflation are heterogeneous across countries in extent and in sign. The paper presented a robust empirical support for the two hypotheses. When the effects of determinants are assumed to be homogenous across countries, the results support the first hypothesis proposing that the debt is less inflationary in economies with well developed financial markets. Hence, the findings in the literature are subject to the development level of the financial sectors of the countries. Also, the results present that the coefficients of variables differ in country groups, which support the second hypothesis suggesting that the relationships are heterogeneous across countries. Therefore contrary to the suggestions in the literature, the effects of determinants on inflation cannot be assumed to be homogeneous, that is, the results in the homogeneous model cannot be generalized (Mustafa, 2008).

In every economy, where expenditure is exogenous and the government taxes are high, the bond financed deficits cannot be sustainable, and ultimately the central bank of the said nation is forced to monetize the deficit gap (Aisen \& Veiga, 2006). The resultant increase in the money supply becomes inflationary in the long term. Lots of studies have successfully examined the impact of the fiscal policy of both the developing and developed nations' inflations. In 1987, Brazil was faced with a huge external debt standing at $\$ 103$ billion, an amount three one third times larger than the country's GDP at that time. The country's requirement for the debt service remained erroneous, and the trade balance was out of reach. The front for inflation was not projected to be good as seen in the figure bellow (Aisen, \& Veiga, 2008). The inflation stayed low for the rest of March 1986 until six months down the line when inflation exploded. By the year 1987, on June, the inflation shot to 800 percent, two times larger than when Brazil introduced their plan. The policy makers thought the inflation could be controlled using a freeze on the prices, which failed to work. Aisen \& Veiga (2006) established that there is a significant relationship between a country foreign and domestic debts and interest rates, budget deficits, and inflation. It is paramount that the external finance deficit pushes both inflation and interest rates higher (Aisen, \& Veiga, 2006).

Reinhart and Rogoff (2009) did not find a relation between high government debt ratios and inflation among advanced nations (except for the case of the United States), but emerging nations suffer as median inflation rises from $6 \%$ per year to $16.5 \%$ per year when they move from a lower debt ratio to a higher debt ratio. Worse, they find that countries rarely grow their way out of high debt ratios. Rather, highly indebted nations engineer default through some combination of rapid inflation or outright repudiation of the debt. Furthermore, the road to recovery after default is not pleasant, with years of depressed GDP, high unemployment, and diminished access to global capital markets. Most importantly, correlation doesn't necessarily mean causation. The authors used Barro's Ricardian equivalence theory in explaining why high levels of debt are correlated with low rates of growth. As people assume that "taxes ultimately need to be raised," they spend less today and lower economic growth rates. High debts are also related to high inflation because governments are tempted to inflate away their debts (Reinhart and Rogoff, 2009).

In a highly discussed paper, Reinhart and Rogoff (2010) used a multi-country historical dataset on public (government debt) to search for a systematic relationship between public debt levels, growth and inflation. The study reported that whereas the link between growth and debt seems relatively weak at "normal" debt levels, median growth rates for countries with public debt over roughly 90 percent of GDP are about one percent lower than otherwise; average (mean) growth rates are several percent lower. The researchers also reported that the relationship between public debt and growth is remarkably similar across emerging markets and advanced economies. However, this was not the case for inflation as the study found no systematic relationship between high debt levels and inflation 
for advanced economies as a group (albeit with individual country exceptions including the United States). By contrast, in emerging market countries, high public debt levels coincided with higher inflation.

According to Reinhard \& Rogoff (2011) the 2007-2009 financial crisis led to a build up of debt. In an investigation of the increase in the level of debt and its effect on macroeconomic variables, the researchers established that average debt levels in Iceland, Ireland, Spain, the United Kingdom, and the United States increased up to $75 \%$, showing an increase of up to $20 \%$ from 2007 to 2009 . The study also reported that the nonlinear effect of external debt was characteristic of debt intolerance, showing that these countries had reached their tolerance limits. The net result was a sharp increase in interest rates, fiscal adjustments, spending cuts, and defaults, and increasing inflation levels.

Putonoi \& Mutuku (2013) analyzed the effect of public debt on economic growth in Kenya. The data covered the period from 2000 to 2010. The study showed that domestic debt rose steady to 2010, with government policy moving towards long term borrowing on the domestic market using treasury bonds. The rise in both domestic and external debt was also associated with an increase in interest rates to $13 \%$. The researchers recommended that there was need to improve the management of debt by transiting from an expansionary policy to tightening policy as a way of curbing the rise in inflation and weakening of the domestic currency.

\section{Methodology}

\subsection{Data Sources}

The paper relied on secondary time series data to empirically assess the effect of external debt on inflation, for the period 1972-2012. Data was collected from the IMF International Financial Statistics database. Efforts were made at ensuring that data sources are consistent for all the variables. All nominal variables were converted to real values measured in Kenya shillings. Data for external debt was converted into financial calendar year to correspond to data on inflation. The consumer price index (CPI) was used as the proxy measure for inflation. The year 1972 was used as the base year due to the availability of data. External debt and inflation reporting before 1972 was inconsistent or unavailable.

\subsection{Model Specification}

A macroeconomic debt growth model using ordinary least square (OLS) regression was used to estimate the relationship between external debt and inflation. The general equation for OLS has been used in other studies, such as Nwanne and Eze (2015) in investigating the effect of external debt servicing on exchange rate in Nigeria, Mahmoud (2015) in investigating the relationship between external debt and economic growth in Mauritania, and Shafi et al (2015) in determining the link between debt and economic growth in Pakistan and India. The model took the form of:

$$
\mathrm{ED}=\mathrm{f}(\mathrm{INF})
$$

Where $E D=$ External debt

$$
\mathrm{INFL}=\text { Inflation }
$$

In stochastic form, the question becomes:

$$
\mathrm{ER}=\beta 0+\beta_{1} \mathrm{INF}+\varepsilon
$$

Where:

$$
\begin{aligned}
& \varepsilon=\text { Error term } \\
& \beta_{1}=\text { slope of the regression equation }
\end{aligned}
$$

To ensure that the data does not violate the assumptions of classical linear regression model (CLRM) and test for stationarity, the study tested for unit tests using Augmented Dickey-Fuller (ADF). To test for the verifiability of the estimated long run model, additional diagnostic tests, notably: heteroskedasticity, autoregressive conditional heteroskedasticity (ARCH), autocorrelation and normality, were carried out. Regression was used to determine the relationship between external debt and inflation.

\section{Results}

\subsection{Preliminary Data Analysis}

This study uses ADF test to test for presence of unit root in external debt and inflation. The ADF was conducted at levels and in first difference. The test results for ADF shows that external debt is stationary at first difference, as reported in Table 1. In other words these variables are integrated of order one I(1). On the other hand, inflation was stationary in levels implying that they are integrated of order zero I(0). Gujarati (2008) argued that to avoid spurious results one should regress variables that are all stationary. Thus the study regresses the first difference of external 
debt, balance of trade, exchange rate, foreign reserves and total investment as a percentage of GDP while GDP growth rate and inflation are regressed in levels.

Table 1. Unit Root Test results

\begin{tabular}{lllllll}
\hline & & Level & & $\begin{array}{l}\text { First } \\
\text { difference }\end{array}$ & Decision \\
\hline Variables & Lag & Drift & Trend & Drift & Trend & Regress in \\
\hline External Debt & 1 & -3.040 & -1.351 & $-3.391(0.0009)$ & $-3.824(0.0154)$ & First \\
& & $(0.0022)$ & $(0.8748)$ & & & Difference \\
Inflation & 1 & -4.153 & -4.370 & $-7.635(0.0000)$ & $-7.514(0.0000)$ & Levels \\
& & $(0.0001)$ & $(0.0024)$ & & & \\
\hline
\end{tabular}

$\mathrm{H}_{0}$ There is unit root; the values in the brackets are the $\mathrm{P}$ values

The study used Breusch-Pagan/Cook-Weisberg test to test for heteroskedasticity, and to establish whether the variance of the error term of the regression model is constant. The Breusch-Pagan/Cook-Weisberg test results show a Chi Square of 0.19 with a p value of 0.6666 , as shown in Table 2. This implies the acceptance of null hypothesis of homoskedasticity. This suggests that the variance of the error term of the regression model is constant and that the data does not suffer from heteroskedasticity.

Table 2. Breusch-Pagan / Cook-Weisberg test for heteroskedasticity

\begin{tabular}{cc}
\hline Chi Square & P Value \\
\hline 0.19 & 0.6666 \\
\hline
\end{tabular}

Ho: Constant variance

Further, the study tested for the presences of Autoregressive Conditional Heteroskedasticity effects using Lagrangian multiplier test. The results show a Chi Square of 0.503 with a $\mathrm{p}$ value of 0.4781 , in Table 3 . This suggests the rejection of the alternative hypothesis that there is ARCH effect in the data. Thus the data does not suffer from autoregressive conditional heteroskedasticity at lag one.

Table 3. LM test for ARCH

\begin{tabular}{|c|c|c|c|}
\hline Lag & Chi Square & Degree of Freedom & P value \\
\hline 1 & 0.503 & 1 & 0.4781 \\
\hline
\end{tabular}

Tests for autocorrelation was done Breusch-Godfrey Lagrangian multiplier test. The test result for first order autocorrelation has a Chi Square of 0.055 and a $\mathrm{p}$ value of 0.8141 while the second order autocorrelation has a Chi Square of 1.860 with a $p$ value of 0.3946 , as reported in Table 4 . Thus, the alternative hypothesis for both first and higher order autocorrelation was rejected. The results suggest that the data does not suffer from serial correlation.

Table 4. Breusch-Godfrey LM test for autocorrelation

\begin{tabular}{cccc}
\hline Lag & Chi Square & Degree of Freedom & P value \\
\hline 1 & 0.055 & 1 & 0.8141 \\
2 & 1.860 & 2 & 0.3946 \\
\hline
\end{tabular}

H0: no serial correlation 
Durbin-Watson d-statistic was used to test for normality and establish whether the error term from the regression model are autoregressive of order one AR (1). The null hypothesis of Durbin-Watson d-statistic is that there is no first order serial autocorrelation. Its values range between 0 and 4 where the value of 2 implies that there is no first order serial autocorrelation. The test results indicate a Durbin-Watson d-statistic of 1.9732 with 9 and 38 degrees of freedom. This value is close to 2 implying that there is no first order serial autocorrelation.

\subsection{Relationship between External Debt and Inflation}

The results for external debt and inflation show a Spearman's correlation coefficient of -0.1768 with a $\mathrm{P}$ value of 0.2687 , as reported in Table 5. This finding implies that external debt and inflation are negatively related but the relationship is not statistically significant since the $\mathrm{P}$ value is greater than 0.05 .

Table 5. Correlation between external debt and inflation

\begin{tabular}{lll}
\hline Number of Observations & Spearman's Rho & P Value \\
\hline 41 & -0.1768 & 0.2687 \\
\hline
\end{tabular}

The relationship between external debt and inflation as shown in the graph may not be explicit since inflation experienced mild fluctuations as external debt increased.

The regression results for inflation on external debt have an F statistic of 7.14 with a p value of 0.0110 , in Table 6 . The $\mathrm{R}$ square is 15.8 percent implying that 15.8 percent of variations in external debt are explained by variations in inflation. Since the R square is less than 50 percent, this finding suggests that that inflation poorly fits the regression model. The coefficient for inflation is 0.0833 and has a $\mathrm{p}$ value of 0.011 implying that inflation has a significant positive effect on external debt.

Table 6. External debt on inflation

\begin{tabular}{|c|c|c|c|c|c|c|}
\hline Source & SS & Df & \multicolumn{2}{|c|}{ MS } & \multicolumn{2}{|l|}{ Number of obs $=40$} \\
\hline & & & & & \multicolumn{2}{|l|}{$\mathrm{F}(1,38)=7.14$} \\
\hline Model & 0.1253 & 1 & \multicolumn{2}{|c|}{0.1253} & \multicolumn{2}{|l|}{ Prob $>F=0.0110$} \\
\hline \multirow[t]{2}{*}{ Residual } & 0.6668 & 38 & \multicolumn{2}{|c|}{0.0175} & \multicolumn{2}{|l|}{$\mathrm{R}$-squared $=0.1582$} \\
\hline & & & & & Adj R-squared $=0.1361$ & \\
\hline \multirow[t]{3}{*}{ Total } & 0.7921 & 39 & \multicolumn{2}{|c|}{0.0203} & \multicolumn{2}{|l|}{ Root $\mathrm{MSE}=0.1324$} \\
\hline & \multirow[t]{2}{*}{ Coefficient } & \multirow{2}{*}{$\begin{array}{l}\text { Standard } \\
\text { Error }\end{array}$} & \multirow[t]{2}{*}{$\mathbf{t}$} & \multirow[t]{2}{*}{$\mathbf{P}>\mathbf{t}$} & \multicolumn{2}{|c|}{ [95\% Confidence Interval] } \\
\hline & & & & & Lower & Upper \\
\hline Inflation & 0.0833 & 0.0312 & 2.67 & 0.011 & 0.0202 & 0.1464 \\
\hline Constant & -0.0619 & 0.0772 & -0.80 & 0.427 & -0.2181 & 0.0943 \\
\hline
\end{tabular}

\section{Discussion of the Results}

Correlation analysis indicated that the relationship between inflation and external debt was negative. The regression findings show that there is a significant relationship between inflation and external debt. This means that increase in inflation increases the level of external debt. High inflation affects monetary stability which is a key factor in credit rating. Poor or lack of monetary stability leads to high interest rate which ultimately leads to high accumulation of external debt levels. In other studies such as Asmamaw (2011), it was reported that inflation is a global concern that continually threatens all economies, whether developed or developing, due to its undesirable effects. Keynesian theories demonstrate that inflation occurs when demands exceeds the potential of the economy (Gebru, 2015).

The results are corroborated by Bhara et al., (2009) who reported that there is a significant relationship between a country's interest rates, budget deficits, foreign and domestic debts to inflation and that external debt pushes both inflation and interest rates higher (Aisen, \& Veiga, 2006). Higher debt levels in emerging economies correlate with 
high inflation (Reinhart \& Rogoff, 2010). The 'safe' debt-to-GDP thresholds depend on a country's default and inflation history, and can be as low as 15\% (Patillo, Poirson, \& Ricci, 2011). The resultant effect of high debt levels create high debt burden and makes debt servicing a threat to economic stability, particularly in developing countries (Suleiman \& Azeez, 2012). Ogunmuyiwa (2011) demonstrated that government debt-to-GDP ratios can have immediate effects on inflation and national solvency in LDCs.

Studies on the relationship between inflation and external debt differ between developing and developed markets. Reinhart and Rogoff (2009) did not find any relationship between high government debt ratios and inflation among advanced nations (except for the case of the United States), but emerging nations suffer as median inflation rises from $6 \%$ per year to $16.5 \%$ per year when they move from a lower debt ratio to a higher debt ratio. The findings also showed that countries rarely grow their way out of high debt ratios. Rather, highly indebted nations engineer default through some combination of rapid inflation or outright repudiation of the debt. The findings also showed that high level of external debt is correlated with high inflation because governments are tempted to inflate away their debts (Reinhart \& Rogoff 2009). Reinhart and Rogoff (2010) suggested that the lack of systematic relationships can be explained by the fact that inflationary pressures are dependent on the level of development of financial markets.

Mustafa (2008) conducted a research to test two main hypotheses: whether external debt is less inflationary when financial markets are well developed, and whether the effects of the determinants of inflation are heterogeneous across countries. The results showed that external debt is less inflationary in economies with well developed financial markets. Further, the coefficients of variables differed in country groups, suggesting that the relationships are heterogeneous across countries. Therefore, the effects of determinants on inflation cannot be assumed to be homogeneous, that is, the results in the homogeneous model cannot be generalized (Mustafa, 2008).

Choong et al (2010) explains the relationship between external debt and inflation by arguing that since a government borrows to plug its budget deficits, external borrowing is eventually monetized and therefore influences inflation. A country with a large debt level is more likely to experience high interest rates leading to the implementation of monetary policies that reduce these rates. The result of such an expansionary policy may reduce interest rates over the short term but lead to higher interest rates and inflation higher or unchanged over the long term.

\section{Conclusion and Recommendations}

The correlation results show that only 15.8 percent of variations in external debt can be explained by variations in inflation. The regression shows that there is a statistically significant relationship between inflation and external debt. Data also shows that Kenya's external debt stocks continue to rise due to the country's inability to generate enough revenue to fund its productive activities. As a result, inflationary pressures arising from an increase in external debt levels will continue to be a macroeconomic issue in the country. The study recommends inflation targeting as a way of maintaining macroeconomic stability. The government should sustain lower inflation rates through tight fiscal and monetary policies, financing of budget deficit from non-inflationary sources, implementation of price stabilization program by subsiding basic food items, and effectively managing external debt.

The significance of this research is that its findings can shape Government of Kenya's public debt management office, in effectively managing ballooning external debt, reduce the cost of debt servicing and minimize debt sustainability risk. They can be utilized by the Central Bank of Kenya and Treasury to inform monetary policy and fiscal policy. Also this study can influence the decision making mechanism of financial institutions such as commercial banks, national and multinationals businesses and institutions whose operation are directly affected by levels and nature of changes of national debt and external debt in particular. This study has generated new evidence on the nature of the relationship and updated knowledge on the external debt management in Kenya. Therefore these findings can be used by researchers, educationists, and scholars in economics and finance to further their studies on the subject matter.

\section{Limitations of the Study and Suggestions for Further Research}

The control of inflation is a central monetary and fiscal policy objective. There are multiple determinants of inflation and diverse macroeconomic models used by Central Banks to implement inflation stabilization programs. As such, this study is limited in scope since it only incorporates the effect of a single variable, external debt, and does not control for other macroeconomic determinants influencing inflation rates. Further studies in Kenya should identify determinants of inflation and examine the comparative effects of each of these determinants to provide an expanded empirical grounding for monetary and fiscal policies.

\section{References}

Abubakar, S. (2011). External Debt and Nigerian Economic Development: An Empirical Investigation. Retrieved from www.abu.edu.ng/publications/2012-04-11(161305) 
Ajayi, L. B., \& Oke, M. O. (2012). Effect of External Debt on Economic Growth and Development of Nigeria. International Journal of Business and Social Science, 3, 12.

Aluko, F., \& Arowolo, D. (2010). Foreign Aid, the Third World's Debt Crisis and the Implication for Economic Development: The Nigeria Experience. African Journal of Political Science and International Relations, 4(4), 120-127.

Asmamaw Mulusew. (2012). Relationship between Inflation and Economic Growth in Ethiopia. Msc thesis in Economic, University of Gonder, June 2012.

Atique, R., \& Malik, K. (2012). Impact of Domestic and External Debt on the Economic Growth of Pakistan. Word Applied Sciences Journal, 20, 120-129.

Baxter, M., \& A. C. Stockman. (2011). Business Cycles and the Exchange Rate Regime. Journal of Monetary Economics, 23, 377-400. http://dx.doi.org/10.1016/0304-3932(89)90039-1

Beaugrand, P., Loko, B., \& Mlachila, M. (2002). The Choice Between External and Domestic Debt in Financing Budget Deficits: The Case of Central and West African Countries. WP/02/79. International Monetary Fund.

Checherita, C., \& Rother, P. (2010, August). The Impact of High and Growing Government Debt on Economic Growth: An Empirical Investigation for the Euro Area. Working Paper Series, No. 1237, The European Central Bank.

Choong, C., Lau, E., Liew, V. K., \& Puah, C. (2010). Does debts foster economic growth? The experience of Malaysia. African Journal of Business Management, 4(8), 1564-1575.

Ezeabasili, V. N., Isu, H. O., \& Mojekwu, J. N. (2011). Nigeria's External Debt and Economic Growth: An Error Correction Approach. International Journal of Business Management, 6(5), 156-170. http://dx.doi.org/10.5539/ijbm.v6n5p156

Gebru, T. (2015). The determinants of economic growth in Ethiopia: A time series analysis. Addis Ababa University.

Hwang, J., Chung, C., \& Wang, C. (2010). Debt Overhang, Financial Sector Development and Economic Growth. Hitotsubashi Journal of Economics, 51(1), 13-30.

IAS. (2014). Budget 2014/2015: Balancing financing concerns while responding to spending inefficiencies. Budget Guide. Institute of Economic Affairs

IEA. (2014). Budget 2013/14: The Onset of the Devolved Government and the Hurdles Ahead. Institute of Economic Analysis.

Mahmoud, L. O. M. (2015). The Role of External Debt on Economic Growth: Evidence from Mauritania. International Journal of Economics and Management Sciences, 4(4), 2-6. http://dx.doi.org/10.4172/2162-6359.1000240

Malik, S., Hayat, M.K., \& Hayat, M.U. (2010). External Debt and Economic Growth: Empirical Evidence from Pakistan. International Research Journal of Finance and Economics, 44, 88-97.

McBride, W. (2012). What is the evidence on taxes and growth? Special Report No. 207. Tax Foundation.

Miller, T., \& Foster, J. D. (2012). Public Debt, Economic Freedom and Growth. Chapter 3 in 2012 Index of Economic Freedom.

Nwanne, T. F. I., \& Eze, O. R. (2015). Assessing the Effect of External Debt Servicing and Receipt on Exchange Rate in Nigeria. International Journal of Economics and Finance, 7(9), 278-286.

Ogunmuviwa, M. S. (2011). Does External Debt Promote Economic Growth in Nigeria? Current Research Journal of Economic Theory, 3(1), 29-35.

Patillo, C., Poirson, H., \& Ricci, L. A. (2011). External Debt and Growth. Review of Economics and Institutions, 2(3), 2-30. http://dx.doi.org/10.5202/rei.v2i3.45

Putonoi, G. K., \& Mutuku, C. M. (2013). Domestic Debt and Economic Growth Nexus in Kenya. Current Research Journal of Economic Theory, 5(1), 1-10.

Reinhart, C., \& K. Rogoff. (2009). This Time is Different: Eight Centuries of Financial Folly. Princeton, NJ: Princeton University Press.

Reinhart, C., \& K. Rogoff. (2009b). Growth in a Time of Debt. Paper prepared for American Economic Review Papers and Proceedings, December 31. 
Reinhart, C., Rogoff, K., \& Savastano, M. (2003). Debt Intolerance. Brookings Paper on Economic Activity, 1, 1-74. http://dx.doi.org/10.1353/eca.2003.0018

Reinhart, Carmen M., \& Kenneth, S. Rogoff. (2010). Growth in a time of debt. American Economic Review, 100(2), 573-578. http://dx.doi.org/10.1257/aer.100.2.573

Saheed, Z.S., Sani, I. E., \& Idakwoji, B. O. (2015). Impact of Public External Debt on Exchange Rate in Nigeria. International Finance and Banking, 2(1), 15-26. http://dx.doi.org/10.5296/ifb.v2i1.7734

Shabbir, S. (2009). Does External Debt Affect Economic Growth: Evidence from Developing Countries. Retrieved September 11, 2015, from http://aysps:gsu.edu/ECON_MA_shabbirs.pdf

Shafi, K., Hua, L., Idrees, Z., \& Nazeer, A. (2015). Relationship of debt and economic growth: The comparative study between Pakistan and India. International Journal of Service Science, Management and Engineering, 2(1), 9-12.

Sulaiman, L. A., \& Azeez, B. A. (2012). Effect of External Debt on Economic Growth of Nigeria. Journal of Economics and Sustainable Development, 3, 8.

The National Treasury. (2015). Budget Statement for the Fiscal Year 2015/2016. Republic of Kenya.

The National Treasury. (2016). Budget Statement for the Fiscal Year 2016/2017. Republic of Kenya.

World Bank. (2014). Country Data: By Topic. The World Bank. 